but we have proof positive that in six or eight days it brings on fever. This is demonstration. Under the system of Hahnemann this sort of proof is impossible. His mode of "testing," as he calls it, is not proof. Its effects are too remote and vague. In the present wild search after germs some may think we have proof of the potency of small forces; but Hahnemann ignored pathology, nor did he seem to inquire into the cause of disease. He said, "If you put liquid medicine in a well-stopped bottle and shake it violently for a while, the patient will feel the effect of the drug on his system." No shaking of the bacillus could get it through the glass bottle into the patient's system. Many germs act quickly and powerfully. If it were necessary, I could easily prove that most homeopathic writers and journals have long since abandoned Hahnemann's wild theories. The homeopathic doctors now give real medicine. A druggist in town has a recipe from one of them for five grains of quinin and one-fourth of a grain of opium, but in the use of medicine for family purposes, put up by the New York Drug Company, authorized by the leading homeopathists, there is no medicine in it worthy of the name. A dose of these pills is from two to four, as a rule. I gave to a man as an experiment forty every two hours for ten days without the least effect. I gave what was known as the most active and energetic poisons. The man ewore before a notary public he never felt the slightest effect of the medicine, and the truth of his statement was verified by the temperature and pulse, taken every two hours. Had Hahnemann's disciples adhered to his dogmas his school would have long since died out here as it has in Germany and France. (It is now dying out in England.) Common sense had to assert itself. An English homeopathic journal some time ago proposed the union of the two schools, and frankly asserted that no serious case was attended throughout by homeopathists without resort to drugs. I referred in my pamphlet to a 3-year-old child in Gloucester County, Virginia, who took $\$ 8$ worth of homeopathic medicine, the entire supply for the whole family for a year, at one time, and received no damage at all. This is another demonstration of the complete inertness of the medicine. There was no cause of disturbance, hence there was no effect.

In conclusion let me say that I am 71 years old, am the friend of all men engaged in the healing art, more so than ever in my life; that I would not willingly hurt any man's feelings or insult his understanding; my whole purpose is to get at what is sound and sensible in physic. We know but little perfectly. I do not remember in my life to have heard any sensible doctor boast of the perfection of his medical knowledge. That was a sad saying of Paul's to his enemies, whom he truly loved and tried to he!p, "Do I offend you because I tell you the truth?" Would it be just and right to tell you a lie and mislead you? Two years ago, by authority of the Governor of Virginia, I visited all the lunatic asylums in the state at the head of a commission, and can frankly say that in my best judgment, of the 2,000 lunatics examined I did not see one man more lost to reason (in medicine) than Samuel Christian Friedrich Hahnemann. I see it has been proposed to build a monument to him on American soil, and would I be true to my convictions to hold my peace? In no sense is insanity a crime; it is a sad misfortune, exciting our profoundest sympathy.

CHRONIC MIDDLE EAR SUPPURATION COMPLICATED WITH SUPPURATING MASTOIDITIS.

PAINFUI DRESSING AFTER OPERATION UNDER HYPNOTIC SUGGESTION.

Read in the Section on Neurology and Medical Jurisprudence, at the Forty-sixth Annual Heeting of the American Medical Association, at Baltimore, Md., May $\overline{7}-10.1895$.

BY FRANK C. TODD, M.D.

FORT WORTH, TEXAS.

Jessie C., aged 10, was brought to me by her father with the following history: Chronic middle ear sup. puration for three years, complicated by a suppurating mastoiditis on either side which had been discharging through large ragged fistulæ. The discharge was profuse, and the child had been obliged to wear a bandage around her head constantly.

The character and chronicity of the affection had caused the child to be very fretful and impatient, though she was not in the least hysterical; and her parents, who were very sympathetic, had humored her to such an extent that she was indeed a spoiled child. The father informed mealso that their family physician, who had been directing a cleansing treatment, had been unable to exercise any control over her whatever. Every time he attempted to do anything the child would cry and say she would not let him touch her; whereupon he would give up the attempt and let her go in the same condition as he had found her.

I therefore recognized that I had a very refractory patient to deal with, and I thought that the management of the disease was not going to be the hardest part of the treatment.

And the first day I found that she came to me with the intention of dealing with me as she had so successfully dealt with my predecessor. It was with some difficulty that I succeeded in making any examination this first day, but I purposely took only a superficial survey on this occasion, finishing my entire exploration only after several visits; making her believe, however, at the end of each séance, that I had done all I desired to. Occasionally I had to inflict discomfort or pain upon her, but before doing so I always informed ber that there was to be some pain, and when she objected I reminded her of former incidents when I had finally accomplished my purpose in spite of her remonstrances, after which reminder she would allow me to do as I chose. However, up to the time of the first dressing, two days after performing a mastoid operation I had given her little pain, and I had realized in the beginning that when it became necessary to unpack a tightly packed, fresh granulating wound, irrigate, and repack again with gauze, there was going to be considerable pain and much more trouble. It was with this painful treatment in view that I had spent so much time in training my patient to my subjection.

She had fought against the administration of the chloroform preparatory for the operation, and this had aroused in her the old spirit of obstinacy, so that when we got her on the table and things had been made ready for the dressing, we found that we were going to have more than we could do to hold her and accomplish our object. The two female nurses were unable to keep her still, either by mental or physical persuasion; she threw her arms about and kicked fiercely. I could not coax her and she knew that I could not hold her and dress her wound at the same 
time, so she resolved to have her own way. But when/shall appropriately designate this entire unit, and I she saw me come toward her with the evident inten- have adopted Waldyer's term of neuron to which, tion of compelling her to obey, she seemed to lose however Prof. Schäfer of London, objects; and while heart, though she continued to scream loudly and apparently resisted all she thought she could.

I placed my left hand on her forehead and passed my right arm over her body, inclosing her arms, and laid her flat on her back, where I held her as in a vice. I then said, "You can not move; you are fastened down." Seeing that her attempts were feeble, I released my hold and repeated the suggestion. This time there was not even an attempt, and she lay as I
held her, but continued to scream. I then said: "Stop crying." She obeyed instantly. Again, I said : "You can not move nor cry, no matter how hard you try." She did neither, while I took time to prepare my hands again and to make a thorough dressing. After I had completed I told her to sit up, as I had finished, which she did immediately. I had told her also that she would feel no pain, and she said afterward that there was none, though the next time I dressed the case, when there would normally have been less, she complained a great deal; this time however it was not necessary to hypnotize her.

This case demonstrates Moll's statement that disobedient people, when hypnotized, are of ten the easiest to manage.

I have purposely made prominent the fact that this patient was brought under control against her desire and in opposition to her strongest efforts. This is somewhat different from any of the cases you mentioned in your recent article-nevertheless an exemplification of your claim that some people can sometimes be hypnotized against their will.

\section{THE NECRON IN MEDICINE.}

Delivered before the Tri-State Medical society held in Des Moines,
Iowa. Oct. 1,2 and 3,1695 . BY SANGER BROWY, M.D.

$$
\text { CHICAGO. }
$$

Some experience in post-graduate teaching has convinced me that the rank and file of the profession pretty generally believe that neurology consists mainly of an intricate tissue of technicalities which only neurologists can understand, if, indeed, the subject is not past all understanding. It ought to be said that this remark applies more properly to students who passed through college, say: prior to seven or eight years ago than to those who are now passing through; because the science has now advanced so far that much of what before was speculation and hypothesis is now susceptible of demonstra. tion, and both student and teacher have shown a correspondingly increased interest. This has been all the greater, because as the science has unfolded, its importance in medicine has been more and more recognized and appreciated.

It is the purpose of this paper not to trace the science of neurology, step by step, from its humble origin to its present eminence, but simply to direct attention to one feature of comparatively recent development which has gone a great way toward facilitating a clear view regarding the etiology, the pathology and treatment of diseases of the nervous system. This feature consists in conceiving the nervous system to be composed of an aggregation of units very similar in character, and in the thorough study of these units.

It is important at the outset to have a name which own are sound, I think Waldyer's term is so familiar and its application so readily understood and accepted that it will come into universal use.

Improved methods of staining, together with close application and great natural aptitude on the part of several students, have resulted in demonstrations. which have added much to our knowledge of the neuron.

$$
\text { . }
$$

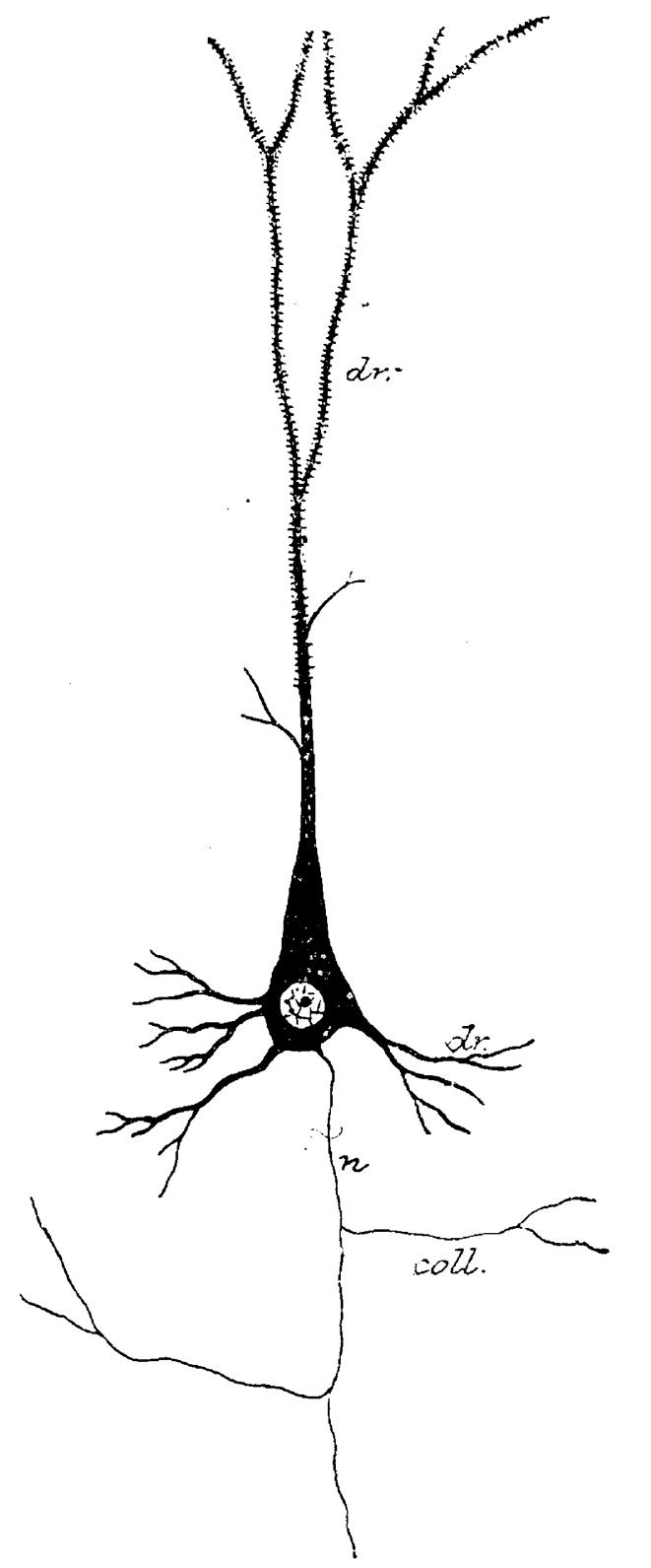

Fig. 1. A projection cell of the cerebral cortex (Schüfer); $d r$, protoplasmic processes; $n$, axis-cylinder process; coll., branch of axis-cylinder process.

Fig. 1, which represents a cell, the body of which is situated in the motor area of the cerebral cortex, may be taken as an illustration of the neuron. It will be seen to consist of a cell body and two processes. The cell body is eeen to contain a prominent nucleus which is large in proportion to the cell body, and the size of both generally bears a distinct relation to the length of the processes which emanate 